\title{
Culturally Important Objects as Signs of Cretan Protolinear Script
}

\author{
Ioannis K. Kenanidis ${ }^{1} \&$ Evangelos C. Papakitsos ${ }^{2}$ \\ ${ }^{1}$ Primary Education Directorate of Kavala, Kavala, Greece \\ ${ }^{2}$ School of Pedagogical and Technological Education, Iraklio Attikis, Greece \\ Correspondence: Ioannis K. Kenanidis, Primary Education Directorate of Kavala, Ethnikis Antistaseos 20,651 10 \\ Kavala, Greece. E-mail: ioakenanid@sch.gr
}

Received: April 30, 2018; Accepted: May 15, 2018; Published: May 19, 2018

\begin{abstract}
This paper presents seven "syllabograms" of the Cretan Protolinear script (signs used for Consonant-Vowel [CV] syllables). This presentation is conducted following the theory of the Cretan Protolinear (CP) script as the one that all the Aegean scripts evolved from, including Linear A, Cretan Hieroglyphics and Linear B. The seven syllabograms of this particular set depict inanimate objects or constructions that were very common or important in everyday life, economy and religion. It is also demonstrated that the phonetic value of each syllabogram corresponds to the Sumerian name of the object depicted by the syllabogram, in a conservative dialect. Thus, more light is shed on the linguistic ancestry of the Aegean scripts, the practice followed for their creation, and, indirectly, on some cultural aspects of the Minoan Civilization.
\end{abstract}

Keywords: Aegean scripts, Cretan Protolinear, Minoan Civilization, Sumerian language, syllabograms

\section{Introduction}

Among the strongest testimonies for cultural contact, affinity or cognateness between two civilizations are language and artefacts; both of them are found within the Aegean scripts that emerged in Bronze Age Crete. These scripts include Linear A (henceforth LA), Cretan Hieroglyphics (CH) and Linear B (LB), all cognate to the Cypriot syllabaries (Davis, 2010). These scripts are syllabaries as they consist of signs (syllabograms) that usually render single syllables of the Consonant-Vowel (CV) form and only very rarely double syllables (Kenanidis \& Papakitsos, 2017a). The syllabograms of the Aegean scripts depict objects, so revealing cultural elements, and they have been devised on the rebus principle, so revealing the language of those who created the Minoan Civilization, regardless of the fact that the Aegean scripts documents available convey various languages. LB conveys the Achaean (Mycenaean) Greek language, while it has been demonstrated that CH conveys an Archaic Sumerian dialect, with some quite meaningful instances (Kenanidis \& Papakitsos, 2017b; Kenanidis, 2016; Papakitsos \& Kenanidis, 2016), although this is not yet universally and unreservedly accepted; as for the language(s) of LA the opinions vary a lot (Kenanidis \& Papakitsos, 2015).

The ancestry of the Aegean scripts is still considered mysterious in mainstream archaeology (Haarmann, 2008), although their direct relation to a conservative Archaic Sumerian dialect has been repeatedly presented (Kenanidis \& Papakitsos, 2018a; 2018b; 2018c; 2017c; Papakitsos \& Kenanidis, 2015), by demonstrating that the syllabograms' phonetic values are equivalent to the Sumerian names of the objects depicted by those signs, through the rebus principle (Fischer, 2004, pp. 34-40). Therefor the herein presentation supports the theory of the Cretan Protolinear script (CP), conceived as the script that all the Bronze Age Aegean scripts (related to Cypro-Minoan) evolved from.

\section{Method}

The existence of CP had been firstly suggested by Willetts (1977, p. 100). Later on, Owens (1996) and Schoep $(1999$, p. 266) suspected or proposed the common ancestry of CH and LA. Kenanidis (1992) initially demonstrated the affinity of LA and LB to a conservative Sumerian dialect, while the paleographic similarity of the Aegean scripts to the Sumerian pictography has been partially demonstrated also by Davis (2011, pp. 65-68). Just a few years ago, an almost complete reconstruction of CP was released in Greek (Kenanidis, 2013).

The methodology for reconstructing the $\mathrm{CP}$ took into account linguistic aspects as well as the contemporary cultural context (Kenanidis \& Papakitsos, 2015). In order to recognize what an ancient sign depicted, it is necessary to trace its pictorial origin in all related scripts (LA, CH, LB and even Cypro-Minoan) and compare to the typical ways of representing objects in the Minoan art, examining in parallel the ways of Sumerian pictography and 
vocabulary. $\mathrm{CP}$ was both pictographic and linear, every sign being a sketch readily recognizable by everyone as a familiar object named by the phonetic value of the sign - what the rebus principle means. In this application of the rebus principle (unlike the acrophonic one), the entire pronounced name of the depicted object was used and not only a part of it. The comparative study considered four factors:

- the object as depicted by sign variants in the Aegean scripts (LA, CH and LB; with lesser aid by CyproMinoan);

- the pictorial similarity or analogy of the studied Minoan sign to equivalent Sumerian ones;

- the phonetic value of the studied sign in the Aegean scripts;

- the proximity of its phonetic value to Sumerian words that denote the depicted object or some directly related concept.

The application of the aforementioned methodology resulted in identifying every sign name as a monosyllabic (rarely disyllabic) Sumerian word that named the depicted object. In this respect, the reader should be reminded of the Sumerian phonotactics which required that the coda consonant of a Sumerian word was silenced, unless the word was followed by a vowel (Kenanidis \& Papakitsos, 2015, p. 336); this feature is indicated here (see section 3. Results) by enclosing the final consonant of a Sumerian word in parentheses. As a representative example, seven syllabograms of $\mathrm{CP}$ will be presented in the next section for the first time to non-Greek readers; these syllabograms depict objects or constructions that were very common or important in everyday life, economy and religion.

\section{Results}

In the following presentation, the main reference for Sumerian vocabulary used is "The Pennsylvania Sumerian Dictionary" of the University of Pennsylvania, abbreviated as "PSD" (Note 1). The images in the figures are retrieved from: the digital archives of the French School of Athens; the Cuneiform Digital Library Initiative (CDLI), where all the images of pre-Cuneiform signs used came from (Note 2); the ATU signs came from Falkenstein (1936); the images for LB came from Ventris \& Chadwick (1953), unless otherwise stated. Cultural information comes from Kenanidis (2013). Finally, the rules of Sumerian phonology mentioned in parentheses (e.g., "rule 5.0.4, p. 34") refer to the specified page in Kenanidis \& Papakitsos (2013).

\subsection{Sign " $y a$ "}

The sign " $\mathrm{ya}$ " was not used in LB because there is no similar syllable in the Greek language. In CP, it depicted a box, called "ĝa" (i.e., "ya") in Sumerian. The shape of this sign in Pre-Cuneiform included variants (fig. 1a), some marking the base of the box or its bottom, others its lid etc. The same is depicted by the equivalent LA syllabogram (fig. 1b), which is more accurately represented in LB as an ideogram (fig. 1c); there is some remote similarity to different ideograms for various kinds of fabric showing a lot of fringes at the bottom, while this one may very rarely have a few legs, and, as a luxurious box, metallic pieces that fasten its sides together. It was the word "ya" that meant "a box", or, by extension, "a small shed" in Sumerian, so the sign was used for "ya". This sign is frequent in $\mathrm{CH}$, an example is the inscription (fig. 1d), which reads "i-na-ši-(sa?)", so second from left is the sign "ya".

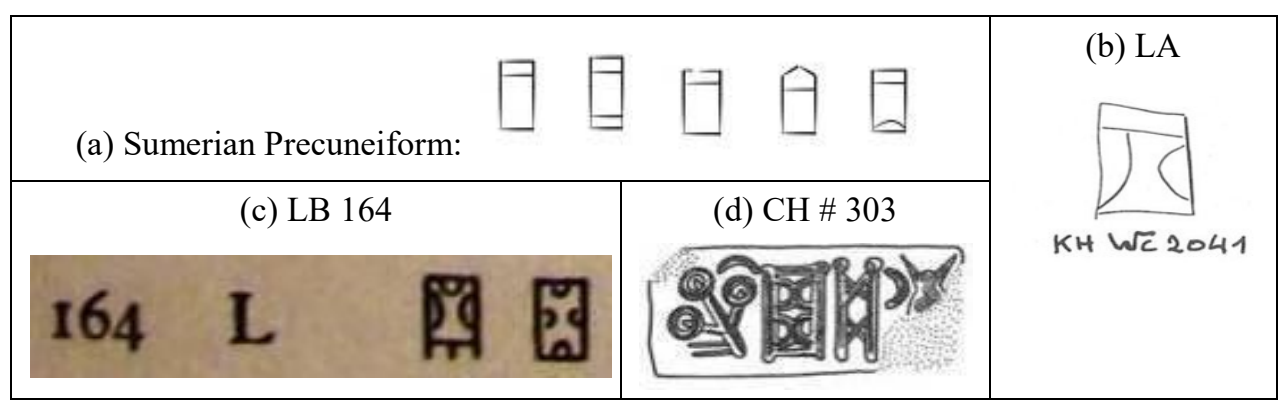

Figure 1. The box sign forms

\subsection{Sign "jo"}

The syllabogram LB 36 (fig. 2a) had already been recognized as an adze in Scripta Minoa by Sir Arthur Evans (1909), who correlated the LB sign with its forms in CH where it is quite common (fig. 2b), as well as with the Egyptian pictogram of an adze; his documentation was perfectly sound, so we know that this syllabogram depicted 
an adze indeed. The adze was "jo" in the Sumerian dialect of Crete.

The word is difficult to trace in the Cuneiform; in PSD, there is no word that specifically means "adze", although "adze" is listed as a secondary meaning to some other words that basically mean types of axes. However, some of

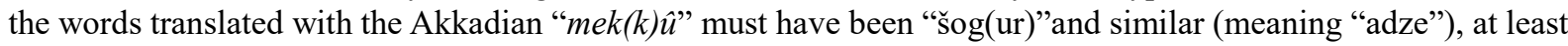
the words "ĝeš igi-ĝal ${ }_{2}$ " and "ĝešsuhur". The word "šukur", seen in the profession called "tug 2 -šu-kar ${ }_{2}$-ak / $\operatorname{tug}_{2}$ šukur-ra / tug $_{2}$-šukur-ur ${ }_{3}$-ra" = "êşiru", originated from an older "joc" (rule 5.0.26, p. 36). This "joc" was the tool that hewed and finely shaped wooden objects, using a pulling motion on the tool while hewing; the signs depict it as a very elaborately made adze, quite better technically designed than the usual adzes of our times. So, when a Minoan saw this syllabogram, instantly recognized it as a "jo(c)" (adze) and recalled the syllable "jo" (by "c" we represent a palatal tense non-aspirate stop).

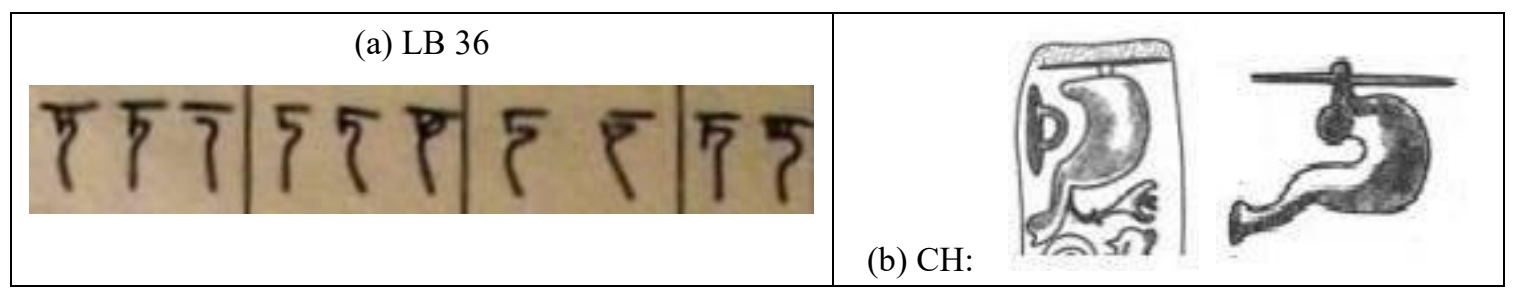

Figure 2. The adze sign forms

\subsection{Sign "me"}

This sign is very neatly written in LB (fig. 3a), and occasionally in LA (fig. 3b) where it is commonly found in the word "a-sa-sa-la-me/ja-sa-sa-la-me" (fig. 3c). Sir Leonard Palmer reasonably conjectured that the word "(j)a-sasa-la-me" means "my Lady" in Luwian, where -me renders the possessive suffix (Palmer, 1958). It is a good conjecture, but possibly erroneous, because he did not know exactly the phonetic value of the signs; for example, he reads "ra" what was "la" in CP. Anyway the occurrences of the word "(j)a-sa-sa-la-me" confirm that all those variants belong to the sign "me" of CP (fig. 3a,b).

What the "me" sign depicted, was exactly the same thing as of the Sumerian Pre-cuneiform "MUŠ 3 " (fig. 3d), also appearing in ATU (fig. 3e). That "MUŠ 3 " was read "mœš" which was possibly the plural of "me" (rule 5.0.4, p. 34), This object could be made of the cheapest materials such as a bundle of reeds, of which the upper soft part front was bent to form a ring like a head inclining to one side, while on the other side the tops of the reeds with their leaves and flowers hung like a tassel. However, since this was a sacred symbol, it would also be made of precious materials, as Christians nowadays may use a Holy Cross made either of cheap wood or of gold. In the picture from a famous vase found in Warka (fig. 3f), we see men and women in a ritual procession to offer the season's first agricultural products to the deity represented by a priestess and two holy symbols (fig. $3 \mathrm{~g}$ ) which are exactly what the CP syllabogram "me" depicted. In Mesopotamia, this object was the sacred symbol of goddess "Inana", whom the Akkadians worshiped under the name "Ištar" that was Hellenized as "Astarte". The Old Testament very often refers to exactly this religious symbol (fig. 3g) as "the Asherah pole", which the nations around the Israelites used to set up in many places to honor their most important goddess.

The goddess, called "Inana" ("the Heavenly Queen") by the Sumerians, progressively over the centuries came to be the most worshipable deity of the Sumerians and neighboring Middle East nations, and her name in Cuneiform was written with the sign "MUŠ 3 " (which all the forms in the fig. 3 belong to); importantly, however, this sacred symbol did not represent the goddess herself, but it represented the "me". We cannot find a word in a modern language to translate Sumerian "me" accurately: "me" was every social institution as, for example, the function of all dignitaries and authorities, the function of all artisans and professionals in every field; every tool or weapon or musical instrument was also a "me"; but also everything that has a command in life, e.g. reproduction, natural calamities and old age, were also "me". "Me" was the answer to every question why that thing must exist in life: it must exist, because it is a "me". So, the closest concept we can find in English, is "authority"; the word was mostly used for the elements of civilization, so different nations had different "me". Because all the "me" of Sumerians were established and safeguarded by the goddess Inana, the Cuneiform sign that represented the "me" stood also for the name "Inana", but the sign itself was the visualization of the "me", so when the Minoans saw this sign, they recognized it as "me", so recalling the syllable "me" (short "e" usually being represented as " $\mathrm{i}$ " in Cuneiform, the Cuneiform "e" typically stands for long "e", so "me" was probably "mē"). 


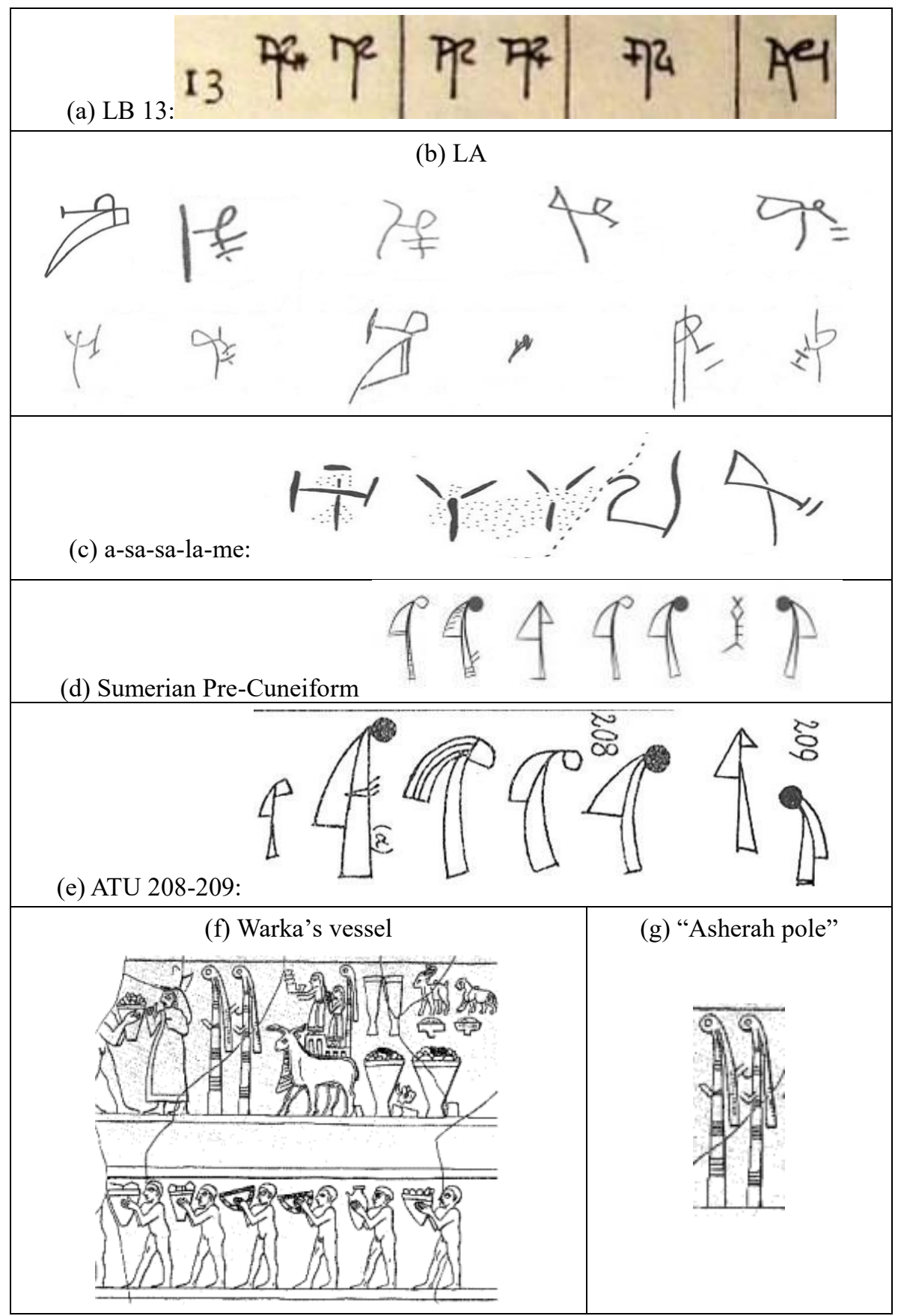

Figure 3. The authority sign forms

\subsection{Sign "ne"}

This syllabogram appears in forms of exaggerated elegance, as it is customary in LB (fig. 4a). In LA this syllabogram has some very naturalistic forms (fig. $4 \mathrm{~b}$ ). It is also found in $\mathrm{CH}$ as on the example of (fig. 4c) where we see the syllabograms "ne-šo-tu" on a seal: the sign "tu" (on the right) depicts an ordinary vessel, quite different to "ne" (on the left) that depicts a vessel of very little capacity, with one handle for comfortably holding with the fingers of one hand and a fine spout for pouring liquid very slowly. This elegant vessel was called "necin" or simply "nec" (without the instrumental suffix -in, see: Kenanidis, 2013, p. 23).

In Sumerian Cuneiform, the word is found as "nigin" (= a libation vessel). As supporters of the monogenesis theory (one common origin of all languages), we find the root of this word also in Old Turkic *nek- (attested as tök- "to pour out") and the Akkadian: naqu "to pour (a libation), sacrifice"; nīqu "offering, sacrifice; libation". Sumerian "nigin" was anciently glossed as $\check{s}^{\#}-q u_{2}^{\#}-u m^{\# \prime " ; ~ " s ̌ a q u}(m)$ " which is the Akkadian verb meaning "to pour 
water, to offer libation, drink or water" and "šāq $(m)$ " is the noun that means the man who offers, or the object that pours, water / drink. The word "nigin" had also the variants "ni 6 ", "niggi $(\mid$ LAGAB.LAGAB $\mid)$ " and "nigi". The "g" of "nigin" is not at all reliable in Cuneiform, see: rule 5.0.39, p. 38). In Sumerian, verb stems could be also used as nouns (like in Old Turkic or English), so the old verb stem "nek" (= to pour) was also a noun meaning "the pouring vessel", which in practice was a holy vessel for libations. The vessel was designed so that the liquid would flow out slowly and ceremonially, as the relevant holy words were recited, and so that the whole content of it would be offered to the deity without demanding a big expense (since the vessel's capacity was so little although the vessel was not small). During ceremonies, or simply to accompany a wish, the libation would be poured out on prepared clean earth or on the famous altar tables found from the Minoan era in Crete (Kenanidis \& Papakitsos, 2017b). So, the holy libation vessel "ne(k)" sketch stood for the syllable "ne".

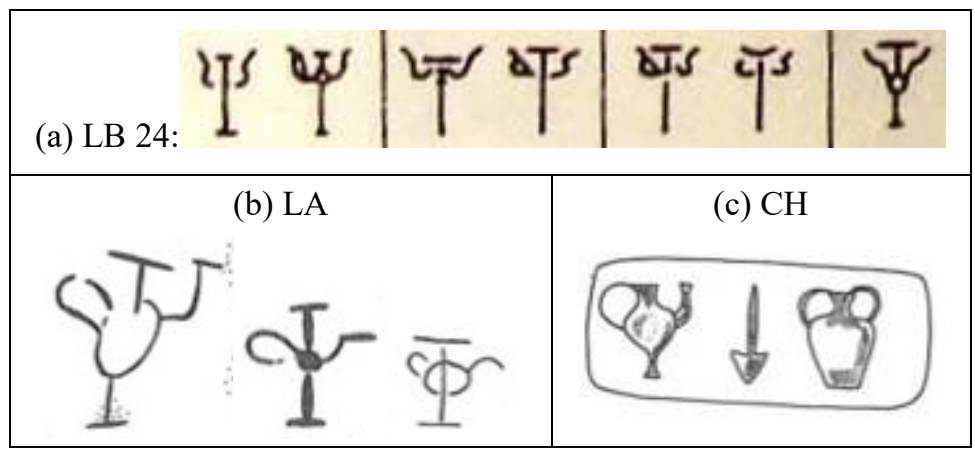

Figure 4. The libation vessel sign forms

\subsection{Sign " $n$ "}

Sign LB 55 (fig. 5a) is not so easily recognizable, partly because of its exquisite elegance. In LA, its forms are more naturalistic (fig. 5b). It was an object consisting of two vertical wooden poles, where a convex thing was attached above and a concave below. This object was a yoke for one animal. Nowadays yokes have somewhat different forms (fig. 5c) but still they are based on the combination of a lower concave and an upper convex or horizontal piece. As far as we can tell from the sign forms, the Sumerian yoke was easier to construct, more practical and more comfortable for the animal. It would also be possible to use strong leather pieces instead of curved wood and indeed some of the LB forms in figure 5a probably show curved parts of leather rather than of wood. From the vertical wooden poles, the yoke was connected to a plough or a wagon.

In old Sumerian, yoke was *ñd or rather *ñuc (rule 5.0.9, p. 35), since the word is an obvious cognate of the Latin "necto" (= con-nect). From the original *ñuc and then *ñud, with the addition of suffix -un (signifying instruments, see: Kenanidis, 2013, p. 23), the word *ñudun was formed, which in Cuneiform Sumerian became "šudun". In

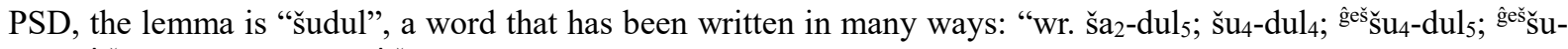

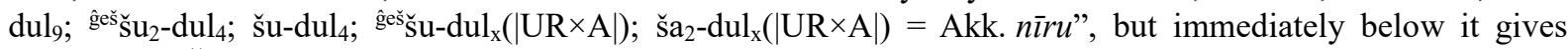

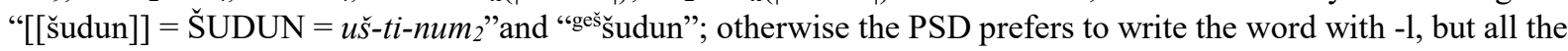
different signs read as "šudul" are also read as "šudun". In addition, the coda "l", could only be pronounced when followed by a vowel, otherwise the signs supposed to end in -1 stood only for "du" that was in fact "du(n)". For example, the sign "DUN 4 ", which the word "šu4-dul 4 " is written with, has the readings "migir ${ }_{2}$, nigir $_{2}$, nimgir 2 , $\breve{s ̆ u d u l}_{4}, \breve{s}_{\text {sudun }} 4$, šutul 4 , šutun 4 ". For the scope of this work it makes no difference whether it was "šudul" or "šudun", because the original word was only *ñuc which became "šud" with some suffixes in Mesopotamia, and "nu(d)" in Crete; simply the forms with -n were more original and probably much more common, because $-\mathrm{n}$ was an original suffix for words signifying instruments; and the same root *nuc through a different evolution became what appears as "migir 2 , nigir 2 , nimgir" (-r suffix for nouns in general).

In conclusion, any Minoan who saw this syllabogram immediately recognized a yoke, called "nu(d)", thus recalling the syllable "nu". 
(a) LB 55

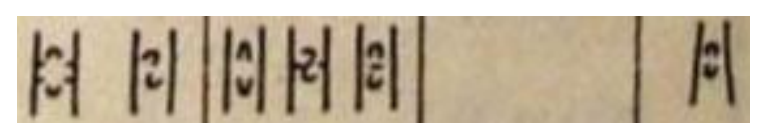

(b) AB 55

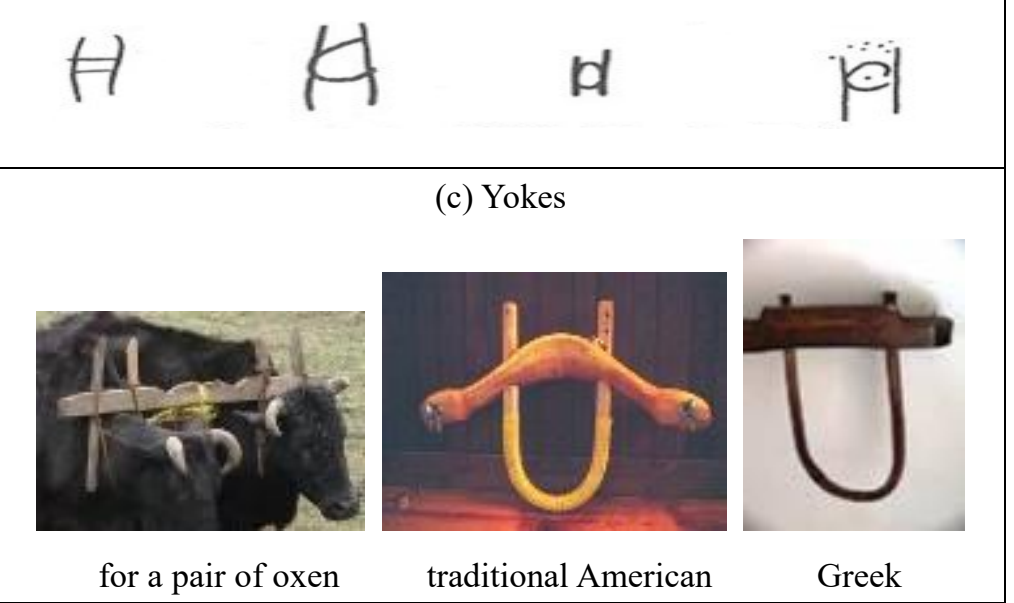

Figure 5. The yoke sign forms

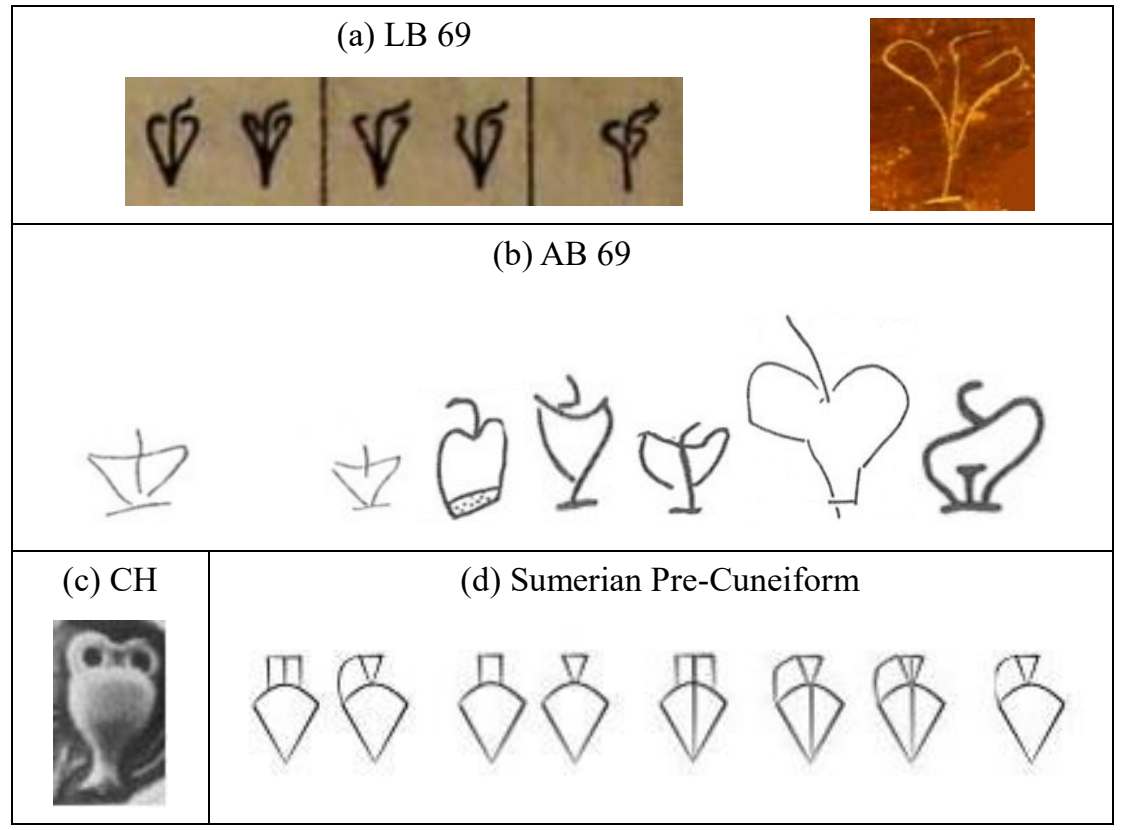

Figure 6. The common vessel sign forms

\subsection{Sign "tu"}

This sign (fig. 6a) depicted the most common type of vessel for storing liquids. The equivalent in LA almost always indicated the bottom of the vessel (fig. 6b). Those vessels, as they had to be moved, had a tapering round bottom (4-5 cm diameter) so they could be rolled on their bottom. Nowadays the seashore of Samothrace Island is strewn with shreds of clay vessels, and especially their narrow round bottoms, that were used in antiquity for the olive oil trade (Kenanidis, 2013). This syllabogram is also found in many inscriptions of CH (fig. 6c), in a form clearly different to that of the libation vessel (fig. 4c).

In Sumerian Cuneiform it usually appears as "dug", but it was never pronounced "dug"; some Akkadian writers rendered it phonetically with a d-, although others did it better with a t-. Falkenstein (1964) observes that vessels were "dug neben tug" (that is, both "tug" and "dug" appeared equally in ancient lexical texts). The correct pronunciation gloss was "tug", and that is attested by Italian "zucca" which comes from the ancient "tug", 
borrowed from Sumerians (Eteocretans) who had settled in Sicily and Southern Italy (given that Sumerian $\mathrm{p}, \mathrm{t}, \mathrm{k}$ were aspirate; $b, d, g$ were non-aspirate and tense, in practice heard as geminated consonants; all unvoiced). This settlement is mythologically related to Daedalus, who left Crete for Sicily, pursued by Minos (Kenanidis, 2013, p. 135). Due to the notorious ambiguity of Cuneiform, the sign is today named DUG, and it was common in the Sumerian Pre-Cuneiform script (fig. 6d). Although there were many types of containers and equally many names for them, "tug" was the general word for all kinds of (normally earthenware) containers, so the sign DUG was used as a determinative sign (not pronounced but classifying words into the category of "vessels, containers").

When a Minoan saw this syllabogram, s/he immediately recognized a familiar container, called "tu(c)" in the Sumerian dialect of Crete, so recalling the syllable "tu".

3.7 Sign "su"

This sign is well-known in LB (fig. 7a) and frequent in LA (fig. 7b) where it has some interesting variant forms, as well as in $\mathrm{CH}$ (fig. 7c). An object as depicted by this sign does not exist in nature; so, this syllabogram represented something artificial. It was the floor plan of a threshing-floor, probably delineated so as to indicate the circular movement of the animals as they threshed the harvested grain stalks.

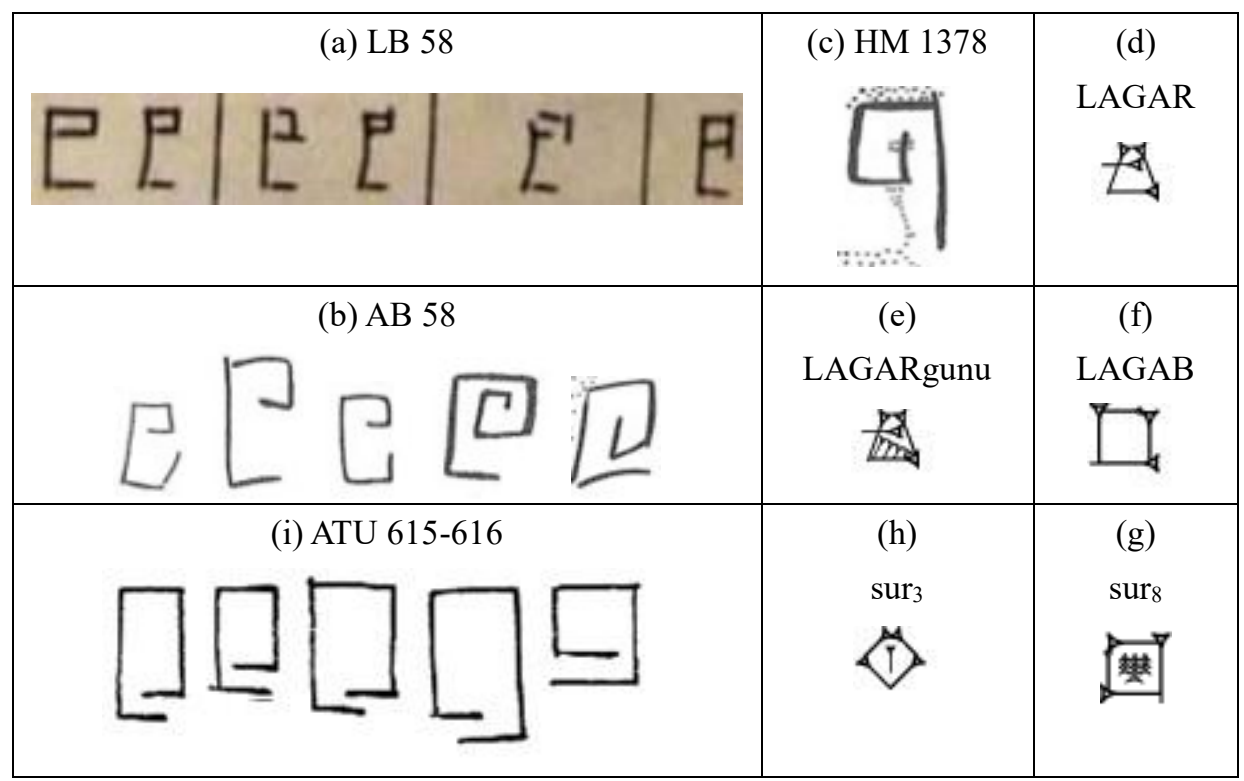

Figure 7. The threshing-floor sign forms

The threshing-floor is a well-known word in Sumerian Cuneiform appearing as "sur 12 " = "sup"; translated by Akkadian maškanu (= literally "place of laying"; threshing floor); nidûtu (literally "abandoning"; also meaning unoccupied land), but in PSD there is no occurrence of the latter gloss to be found, only the following ancient lexical lemmata:

$\left[\left[\mathrm{su}_{7}\right]\right]=\mathrm{su}-\mathrm{u}=\mathrm{LAGAR} \times \check{\mathrm{S} E}=m a-a \check{s}-k a-n u-[u m]$

$\left[\left[\mathrm{su}_{7}\right]\right]===m a-a g-r a-n u-u m^{\#}$

$\left[\left[\mathrm{su}_{7}\right]\right]=[\ldots]=[\mathrm{LAGAR} \times \check{\mathrm{S}} \mathrm{E}]=m a^{\#}-a \check{s}-k a^{\#}-n u-u m$

also in ETCSL (Note 3): "sur 12 " = threshing floor; the word has only the meaning "threshing-floor". So Cuneiform "sur ${ }_{12}$ " = "su7" is written with the sign LAGAR (fig. 7d) with ŠE (= cereals) inside, rarely with LAGARgunu (fig. 7e) where the "gunu" element is a simplification of the grains image in the floor. The sign LAGAB (fig. 7f) would seem at least equally convenient to sketch a threshing-floor, and indeed it has the readings su " (LAGAB) or "sur " (LAGAB). The sign "sur [UNMNG] wr. sur 3 ; surs" (of unknown meaning according to PSD), also meant a threshing-floor, since "surs" (fig. 7g) is LAGAB (= sketch of floor plan) with "zar 3 " (= cereal stacks) in it, while "sur 3" (fig. 7h) is simpler as a floor plan with something in it. The signs ATU 615-616 (fig. 7i) are practically identical to the "su" of CP, and they cannot seem to depict anything else, so probably ATU 615-616 meant "a threshing floor", "su(r)". 
This CP sign was recognized by every Minoan as a threshing-floor, called "su(r)", so bringing to mind the syllable "su".

\section{Discussion \& Conclusion}

This study, based on the concept of Cretan Protolinear (CP) script being the origin of all Aegean scripts of the Bronze Age, has shown the pictorial origin and phonetic use of seven CP syllabograms which depicted objects or constructions that were very common or important in everyday life, economy and religion. In addition, it has been demonstrated how the phonetic value of each presented syllabogram corresponds to the Sumerian name (in a conservative dialect) of the object depicted by the syllabogram. Accordingly, more light is shed on the linguistic ancestry of the Aegean scripts, the practice followed for the creation of $\mathrm{CP}$ and the traits of its descendant scripts, as well as several cultural aspects of the Minoan Civilization, regarding religion and economy.

\section{Acknowledgments}

The authors would like to express their thankfulness to the French School of Athens. Its digital archives greatly facilitated the research presented here. Also, this work would be quite inferior if there were not the Cuneiform Digital Library Initiative (CDLI). Even the main dictionary for Sumerian today (the PSD) is available at the CDLI's tools webpage.

\section{References}

Davis, B. (2010). Introduction to the Aegean Pre-Alphabetic Scripts. KUBABA, 1, 38-61. Retrieved from http://www.fcsh.unl.pt/kubaba/KUBABA/kubaba_1_2010.html

Evans, A. J. (1909). Scripta Minoa: The Written Documents of Minoan Crete: with Special Reference to the Archives of Knossos, Volume I: The Hieroglyphic and Primitive Linear Classes: with an account of the discovery of the pre-Phoenician scripts, their place in the Minoan story and their Mediterranean relatives: with plates, tables and figures in the text. Oxford.

Falkenstein, A. (1936). Archaische Texte aus Uruk (ATU). Ausgrabungen der Deutschen Forschungsgemeinschaft in Uruk - Warka (volume II). Berlin.

Falkenstein, A. (1964). Das Sumerische. Handbuch Der Orientalistik. Leiden: E. J. Brill.

Fischer, S. R. (2004). History of Writing. London: Reaktion Books.

Haarmann, H. (2008). The Danube Script and Other Ancient Writing Systems: A Typology of Distinctive Features. Journal of Archaeomythology, 4(1), 12-46. Retrieved from https://www.archaeomythology.org/publications/the-journal-of-archaeomythology/2008-volume-4/

Kenanidis, I. (1992). Eteokreetes Megaleetores. Athens: National Library of Greece (in Greek).

Kenanidis, I. (2013). Historical and Linguistic Studies: cwepeker.doc. Kavala, Greece: E.P. Lazidou (in Greek).

Kenanidis, I. K. (2016). A 17th c. BC Minoan Votive Double Axe (Labrys). The Arkalochori Axe and its siblings. Anistoriton Journal, In Situ 15(1), 1-20. Retrieved from http://www.anistor.gr/english/enback/2016_1s_Anistoriton.pdf

Kenanidis, I., \& Papakitsos, E. C. (2013). Yet another suggestion about the origins of the Sumerian language. International Journal of Linguistics, 5(5), 30-44. https://doi.org/10.5296/ijl.v5i5.4107

Kenanidis, I. K., \& Papakitsos, E. C. (2015). A Comparative Linguistic Study about the Sumerian Influence on the Creation of the Aegean Scripts. Scholars Journal of Arts, Humanities and Social Sciences, 3(1E), 332-346. Retrieved from http://saspjournals.com/sjahss-31/

Kenanidis, I. K., \& Papakitsos, E. C. (2017a). Linguistic and Cultural Aspects of Disyllabic Signs in the Cretan Protolinear Script. Scholars Bulletin, 3(10), 489-496. https://doi.org/10.21276/sb.2017.3.10.9

Kenanidis, I. K., \& Papakitsos, E. C. (2017b). An Interpretation of the Malia Stone Inscription in Terms of the Cretan Protolinear Script. Terra Sebus. Acta Musei Sabesiensis, 9, 43-56. Retrieved from https://www.cclbsebes.ro/muzeul-municipal-ioan-raica/terra-sebus-nr9.html

Kenanidis, I. K., \& Papakitsos, E. C. (2017c). A Decipherment of the Eteocretan Inscription from Psychro (Crete). Asian Research Journal of Arts \& Social Sciences, 4(3), 1-10. https://doi.org/10.9734/ARJASS/2017/36988

Kenanidis, I. K., \& Papakitsos, E. C. (2018a). Cretan Protolinear Script: The Sixth-Vowel Set of Syllabograms. International Linguistics Research, 1(1), 32-48. https://doi.org/10.30560/ilr.v1n1p32

Kenanidis, I. K., \& Papakitsos, E. C. (2018b). Some syllabograms of the animal category in the Cretan Protolinear 
Script. Migration \& Diffusion, 2018(Article 9), 1-13. Retrieved from http://www.migrationdiffusion.info/article.php?year $=2018$

Kenanidis, I., \& Papakitsos, E. C. (2018c). Cretan Protolinear Script: Some Syllabograms of Human Theme. World Wide Journal of Multidisciplinary Research and Development, 4(2), 370-372. Retrieved from https://www.wwjmrd.com/archive/2018/2

Owens, G. A. (1996). The Common Origin of Cretan Hieroglyphs and Linear A. Kadmos, 35(2), 105-110. https://doi.org/10.1515/kadm.1996.35.2.105

Palmer, L. R. (1958). Luvian and Linear A. Transactions of the Philological Society, 8, 75- 100. https://doi.org/10.1111/j.1467-968X.1958.tb01273.x

Papakitsos, E. C., \& Kenanidis, I. K. (2015). Additional Palaeographic Evidence for the Relationship of the Aegean Scripts to the Sumerian Pictography. Scholars Journal of Arts, Humanities and Social Sciences, 3(3C), 734737. Retrieved from http://saspjournals.com/sjahss-33/

Papakitsos, E. C., \& Kenanidis, I. K. (2016). Cretan Hieroglyphics: The Ornamental and Ritual Version of the Cretan Protolinear Script. Anistoriton Journal, Essays 15(2), 1-12. Retrieved from http://www.anistor.gr/english/enback/2016_2e_Anistoriton.pdf

Schoep, I. (1999). The Origins of Writing and Administration on Crete. Oxford Journal of Archaeology, 18(3), 265-276. https://doi.org/10.1111/1468-0092.00083

Ventris, M. G. F., \& Chadwick, J. (1953). Documents in Mycenaean Greek. Cambridge: Cambridge University Press.

Willetts, R. F. (1977). The Civilization of Ancient Crete. Oakland, CA: University of California Press.

Davis, B. (2011). Cypro-Minoan in Philistia? KUBABA, 2, 40-74. Retrieved from http://www.fcsh.unl.pt/kubaba/KUBABA/kubaba_2_2011.html

\section{Notes}

Note 1. Available at: http://psd.museum.upenn.edu/epsd/index.html

Note 2. Available at: https://cdli.ucla.edu/tools/SignLists/protocuneiform/archsigns.html

Note 3. Electronic Text Corpus of Sumerian Literature, available at: http://etcsl.orinst.ox.ac.uk/

\section{Copyrights}

Copyright for this article is retained by the author(s), with first publication rights granted to the journal.

This is an open-access article distributed under the terms and conditions of the Creative Commons Attribution license (http://creativecommons.org/licenses/by/4.0/). 